\title{
Effect of Hydrodynamic Conditions of Photobioreactors on Lipids Productivity in Microalgae
}

\author{
Juan Carlos Robles Heredia, Asteria Narváez García, \\ Alejandro Ruiz Marin, Yunuen Canedo Lopez, \\ Jose del Carmen Zavala Loria and \\ Julio Cesar Sacramento Rivero
}

Additional information is available at the end of the chapter

http://dx.doi.org/10.5772/intechopen.74134

\begin{abstract}
This research presents the effect of hydrodynamic conditions at different rates of aeration $(1.4,1.8$, and $2.3 \mathrm{vvm})$ and the geometry of two photobioreactors with internal lighting on lipid productivity and other parameters of Chlorella vulgaris. A two-step nitrogenreduction cultivation mode was applied for promoting lipid accumulation. The inoculum was cultivated initially at $90 \mathrm{mg} \mathrm{L}^{-1} \mathrm{~N}^{-N_{4}^{+}}$, and at the end of the exponential phase, it was fed to $11 \mathrm{~L}$ photobioreactor at $20 \mathrm{mg} \mathrm{L}^{-1}$ of $\mathrm{N}_{-\mathrm{NH}_{4}+}$. The results showed that with similar aeration rates, the hydrodynamic regime in both photobioreactors was different. However, the increase in shear rate and agitation did not cause cell damage or photoinhibition. The maximum cell growth was $12 \times 10^{6}$ cells $\mathrm{mL}^{-1}$. The highest consumption of nitrogen was $19 \%$ and shear rates were of $120-340 \mathrm{~s}^{-1}$. The highest lipid productivity was reached in bubble column at $1.8 \mathrm{vvm}$ with $0.650 \mathrm{mg} \cdot \mathrm{L}^{-1} \mathrm{~d}^{-1}$.
\end{abstract}

Keywords: shear rate, aeration rate, photobioreactors, Chlorella vulgaris, nitrogen limitation

\section{Introduction}

Several reports have demonstrated that certain species of microalgae can store large amounts of triacylglycerol (TAG), which are the raw materials for biodiesel production. The mixture of saturated and unsaturated fatty acid chains $\left(\mathrm{C}_{12}-\mathrm{C}_{22}\right)$ present in many microalgae favors the production of biodiesel [1, 2]. Certain species of microalgae tend to reach a high lipid content 
(20-50\% dry cell weight) and may increase it by controlling various biotic and abiotic factors of the crop, such as light intensity, photoperiod, temperature, nutrients, mode, and the intensity of agitation [3]. The total yield of lipids from microalgae depends not only on the concentration of biomass reached but also on the cellular oil content. It should be noted that understress conditions by nutrient limitation, cell growth tends to decrease, while lipid content increases $[4,5]$; therefore, the most important variable to maximize biodiesel production from microalgae cultures is lipid productivity considered in grams of lipids per liter of culture per day $[5,6]$. The cultivation of microalgae to industrial scale can be performed in open systems such as ponds (raceways) and closed systems called photobioreactors (PBR). In both systems, the source and intensity of light are critical factors affecting phototrophic growth performance of microalgae [1]. The open systems usually are less expensive to build and operate; they are more durable than PBR and have greater production capacity. However, they require more land extension, more susceptible to weather conditions without temperature control and lighting prone to contamination and self-shadowing, which can lead the culture to total collapse [7]. The PBRs have certain advantages such as better control over culture and growth conditions, prevention of evaporation, loss reduction of $\mathrm{CO}_{2}$, higher cell densities, volumetric productivities, greater safety and protection of the environment, and less invasion by microorganisms. Similarly, these equipments show some disadvantages such as overheating, oxygen accumulation, difficulty in scaling, high cost of construction and operation, possible cellular stress damage by shear, and deterioration of the material used in the photo-step $[4,8]$. These disadvantages can be solved by an adequate reactor design. Mixing is an important variable, since it ensures that the cells within the equipment can access the light and prevent the accumulation of oxygen in the culture medium, preventing the precipitation of the cells or their adhesion to the walls of the equipment. For any type of PBR used in the algal culture, efficient mixing is required in order to produce a uniform dispersion of the microalgae in the culture medium, thus eliminating concentration, light, nutrient, and temperature gradients. However, high speeds often are not practical because the shear rates that often damage cells are increased [9]. It has been documented that excessive mechanical agitation creates turbulence, which can cause permanent damage to the cellular structure affecting the growth and production of metabolites; conversely, a poor agitation can cause sedimentation and cell death $[4,7,8]$. Within the vertical column PBR, two configurations can be mentioned: airlift type and conventional bubble column. In comparison with the horizontal type, these present a better degassing, preventing the accumulation of oxygen and not inhibiting algal growth. The bubble column is a simple container in which the gas is injected from the bottom and random mixing is produced by rising bubbles. An airlift reactor consists of two flow regions, downcomer and riser, which can be arranged concentrically or connected cyclically. The continuous movement of the liquid and its consequent mixing capacity is due to the constant addition of a gas stream in the ascending zone, generating a forced convection for the liquid $[8,10,11]$. The hydrodynamic differences in these equipments can affect the physical and biochemical properties of microalgal cells during the culture process. Due to these differences, it can be mentioned that at the same aeration rate, the airlift configuration can cause greater turbulence and poor cell growth due to the phenomenon of photoinhibition due to excess light by the number of times that cells access the light source and other negative aspects such as hydrodynamic shear stress [8]. The interest of this study was to evaluate the effect of hydrodynamic 
conditions at different aeration rates on lipid productivity and other parameters of Chlorella vulgaris in cultures with nitrogen limitation using two PBRs (bubble column and airlift).

\section{Materials and methods}

\subsection{Selection of strain and culture medium}

The Chlorella vulgaris microalga was obtained from the Cepario of the Center for Scientific Research and Higher Education of Ensenada (CICESE), Mexico. C. vulgaris was selected because of its high potential for the production of biodiesel, from its high productivity and fatty acid profile [6], as well as the capacity to develop in urban wastewater, commercial media, and nitrogen limitation conditions [12-15]. For acclimation, C. vulgaris was cultivated in culture medium at $\mathrm{pH}=7$, with a composition similar to the effluent from the primary treatment of an urban wastewater treatment plant as follows [16]: $7 \mathrm{mg} \mathrm{NaCl}, 4 \mathrm{mg} \mathrm{CaCl}{ }_{2}$ $2 \mathrm{mg} \mathrm{MgSO} \cdot 7 \mathrm{H}_{2} \mathrm{O}, 15 \mathrm{mg} \mathrm{KH} \mathrm{PO}_{4^{\prime}}$ and $115.6 \mathrm{mg} \mathrm{NH} 4 \mathrm{Cl}$, all dissolved in $1 \mathrm{~L}$ of distilled water. Trace metals and vitamins were aggregated according to medium $\mathrm{f} / 2$ of Guillard and Ryther [17]. During acclimation (1 month), the microalgae was transferred to fresh culture medium every 7 days at $28 \pm 1^{\circ} \mathrm{C}$ and a light intensity of $100 \mu \mathrm{E} \mathrm{m}^{-2} \mathrm{~s}^{-1}$.

\subsection{Cultivation process}

When starting the experiments, C. vulgaris was cultivated in an enriched medium at $90 \mathrm{mg} \mathrm{L}^{-1}$ nitrogen; subsequently, the concentration of the culture was reduced to $20 \mathrm{mg} \mathrm{L}^{-1}$, similarly to that described by Robles-Heredia et al. [3]. Of the stock culture, a fraction was taken and transferred to the four bubble column seedlings, adding $200 \mathrm{~mL}$ each to one cell concentration of $15 \times 10^{4}$ cells $\mathrm{mL}^{-1}$ (Section 2.1). Fresh culture medium was added, starting the culture to a concentration of $90 \mathrm{mg} \mathrm{L}^{-1}$ of $\mathrm{N}$ and volume of operation of $2.5 \mathrm{~L}$; continuous aeration of $0.4 \mathrm{vvm}$ (volumetric flow of air per minute per unit volume of medium) and external white light illumination at a light intensity of $225 \mu \mathrm{E} \mathrm{m}^{-2} \mathrm{~s}^{-1}$ were supplied. Cell growth was monitored by cell counting in the Neubauer chamber using an optical microscope with a $40 \times$ lens. During the exponential growth phase (5 days), the volume of the four seedbeds was diluted $(40-50 \%)$ to inoculate two 11 L PBRs, so that when the fresh medium was added, the initial concentration of $\mathrm{N}^{-\mathrm{NH}_{4}+}$ in the medium was $20 \mathrm{mg} \mathrm{L}^{-1}$. The cultures were maintained and monitored for 5 days, during which $100 \mathrm{~mL}$ of each reactor, dry biomass, $\mathrm{N}^{-\mathrm{NH}_{4}+}$ consumption, and lipid productivity every $24 \mathrm{~h}$ were sampled to determine cell counts in the Neubauer chamber every $12 \mathrm{~h}$.

\subsection{Photobioreactor test}

The culture was realized at the same time in two PBRs, airlift (RAF) and bubble column (COB), both with an operating volume of $11 \mathrm{~L}$ and a height of $95 \mathrm{~cm}$. The COB consists of two vertical concentric glass tubes; the light source is a fluorescent white light lamp located inside the inner tube, with an intensity of $300 \mu \mathrm{E} \mathrm{m}^{-2} \mathrm{~s}^{-1}$. The radial light path (distance between the outside of the inner tube and the inside of the outer tube) is $5 \mathrm{~cm}$ so as not to favor self-shadowing. 
The air was injected through four cylindrical diffusers made of plastic material and porous structure distributed radially in the base. In the $\mathrm{COB}$ reactor, the flow of injected air drives the culture medium to the top, and, by gravity, the cells descend; this mixing process is continuous for the duration of the culture period. As for the RAF reactor, the construction is the same as the COB reactor, but with the addition of a transparent acrylic tube or draft tube between the inner lighting tube and the outer tube, so that mixing is carried out by airlift effect. The air is injected into the section formed between the baffle and the inner tubes, where the riser is made and in the upper part of the baffle the fluid descends (downcomer) between the baffle and the external glass tubes. Design parameters correspond to a working volume of $11 \mathrm{~L}\left(0.011 \mathrm{~m}^{3}\right)$ of culture medium with rate $\mathrm{L} / \mathrm{D}$ and illuminated surface/ volume medium in $\mathrm{m}^{-1}$ (3.6 and 10.9) for COB, whereas in RAF it was 4.0 and $12.1 \mathrm{~m}^{-1}$, respectively. Other parameters required are the following: $h_{L}$ in $\mathrm{m}$ is the height of the liquid at rest without gas flow (liquid holdup), for COB it is 0.8 , while in RAF it was $0.86 ; h_{G}$ is the height of the column including gas retention; $h_{B}$ is the distance between the base and the deflector $(0.05 \mathrm{~m})$; $d_{0}$ is the inner diameter of the outer tube $(0.144 \mathrm{~m})$; and $d_{b i}=0.0953 \mathrm{~m}$ and $d_{b o}=0.1016 \mathrm{~m}$ are the internal and external diameters of the deflector, respectively. Sectional area in the PBRs is $A_{c}=0.0140 \mathrm{~m}$ in COB, and $A_{r}=0.0048 \mathrm{~m}$ and $A_{d}=0.0082 \mathrm{~m}$ are the sectional areas in the riser and downcomer of the RAF, respectively. Letters $A, B$, C, E, F, G, and $\mathrm{H}$ in that order consider the common parts of both PBRs, degassing valve, top cover, top cover flange, outer tube, central tube for lighting, lower cover flange, and diffusers-silencers.

The main dimensions of both PBRs are shown in Figure 1a and $\mathbf{b}$.

The shaded area in RAF is the so-called free area between the riser and the downcomer $h_{B^{\prime}}$ $\mathrm{Cr}$ is a clamping ring, and D is a Baffle tube. Section $A_{b}$ is the free area between the riser and downcomer in the RAF and corresponds to the surface of an imaginary cylinder of diameter $d_{b o}$ and height $h_{B}$ (see Figure 1a and $\mathbf{b}$ ).

\subsection{Experimental design}

The effect of different operating conditions on lipid productivity was estimated using a $2 \times 3$ factorial design with two replicates, with lipid productivity as a variable response, considering the factors such as PBR geometry in two levels (RAF and COB) and aeration rate in three levels $(1.4,1.8$, and $2.3 \mathrm{vvm}$ ) and using aeration as inferior limit with $0.91 \mathrm{vvm}$ in RAF and as upper limit $3.4 \mathrm{vvm}$ in COB. The geometry of the PBR is related to the shear rate that predominates in the same, being expected a higher shear rate in the RAF riser than in the COB. The results of the experimental design were analyzed using a complete factorial analysis of variance (ANOVA) ( $\alpha$ : 0.05) using STATISTICA V7 program [18].

\subsection{Shear rate}

To relate the geometry of the PBR (bubble column or airlift) with the prevailing shear rate within the same, it is recognized that the characteristic shear rate $(\gamma)$ in the PBR is a function of the surface velocity of the $U_{g}$ gas, so that Eq. (1)

$$
\gamma=1000 U_{g}^{2}
$$




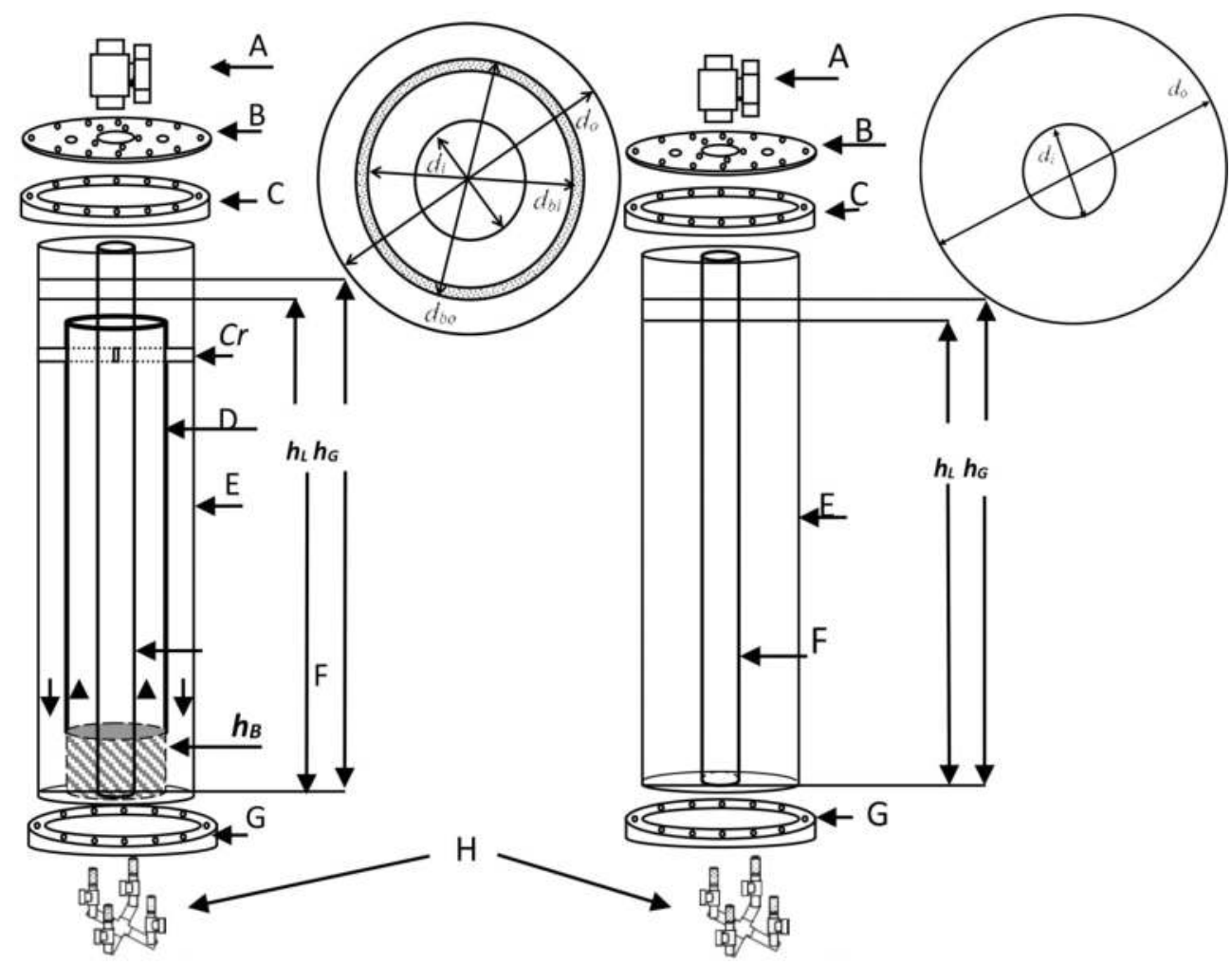

Figure 1. (a) Photobioreactor RAF and (b) photobioreactor COB.

Equation (1) is valid in the range of $0.008<U g<0.09 \mathrm{~m} \mathrm{~s}^{-1}$ and $1000 \mathrm{~m}^{-1}$ for airlift column [19]. For the case of the airlift, the characteristic shear rate exists in the riser, and the shear rate is calculated with the same Eq. (1) but using the speed of the gas in the riser $U_{g r}$. The pneumatic power $\left(P G / V_{L}\right)$ given in $\mathrm{Wm}^{-3}$ is considered as the energy or power generated by the inflow of gas or air injected to the equipment to be exerted by expansion of the movement of agitation of the fluid inside the photobioreactor. For a bubble column, pneumatic power is calculated with Eq. (2) [20]:

$$
\frac{P G}{V_{L}}=\rho \cdot L_{g} \cdot U_{g}
$$

The pneumatic power in an airlift reactor [21] is evaluated by means of Eq. (3):

$$
\frac{P G}{V_{L}}=\rho \cdot L_{g} \cdot U_{g r}\left(\frac{A_{r}}{A_{r}+A_{d}}\right)
$$

where $U_{g}$ is calculated with Eq. (4)

$$
U_{g}=U_{g r}\left(\frac{A_{r}}{A_{r}+A_{d}}\right)
$$

As can be seen, the pneumatic power in both PBRs is the same for each value of the aeration rate. 


\subsection{Lipid productivity}

After 5 days of the cultivation stage in both PBRs, algal biomass was obtained by means of a flocculation process using a chitosan solution according to the technique of Romero and Ferrán [22], modified for this job, it was considered to chitosan was used for its properties of cell immobilization and avoid dispersion [23]. Subsequently, the harvested biomass was lyophilized for $48 \mathrm{~h}$, at a temperature of $-40^{\circ} \mathrm{C}$ and a pressure of $0.133 \mathrm{mbar}$. The determination of total lipids was performed by the method reported by Bligh and Dyer [24], which is modified as follows: a $10 \mathrm{mg}$ sample of lyophilized biomass was placed in each tube and mixed with $4 \mathrm{~mL}$ of methanol, $2 \mathrm{~mL}$ of chloroform, and $0.5 \mathrm{~mL}$ of distilled water. The mixture was sonificated for $15 \mathrm{~min}$ and subsequently to centrifugation at $4000 \mathrm{rpm}$ for $15 \mathrm{~min}$; the supernatant was removed, to which $2 \mathrm{~mL}$ of distilled water was added and vigorously stirred. It was centrifuged again at $4000 \mathrm{rpm}$ for $15 \mathrm{~min}$ to observe the biphase. With Pasteur pipette, the upper aqueous phase was removed, and the lower lipid-chloroform phase was dried with nitrogen gas to remove the chloroform and concentrate lipids. Subsequently to this concentrate, $3 \mathrm{~mL}$ of $2 \%$ potassium dichromate was added in each tube and placed in a water bath at $100^{\circ} \mathrm{C}$ for $15 \mathrm{~min}$. After cooling in a water bath, $4.5 \mathrm{~mL}$ of distilled water was added, vigorously stirred, and cooled to room temperature to read absorbance in the spectrophotometer at $590 \mathrm{~nm}$. It is important to indicate that the same preparation sequence was followed in two tubes but without lyophilized biomass in the calibration of the spectrophotometer. Previously, the absorbance value A correlated with the $C_{L}$ lipid concentration (in $\mathrm{mg} \mathrm{L}^{-1}$ ), using a tripalmitin standard, resulting in the equation (5):

$$
C_{L}=0.5874 A-0.036 \text { with } r^{2}=0.99
$$

The lipid content of the sample is considered as the lipid composition in $\left(\% \mathrm{ww}^{-1}\right)$ on dry basis $\mathrm{w}$, and this in turn results in a $\mathrm{P}_{\mathrm{L}}$ lipid productivity (in $\mathrm{mg} \mathrm{L}^{-1} \mathrm{~d}^{-1}$ ) with the following equation (6):

$$
P_{L}=\frac{w_{1} X_{1}-w_{2} X_{2}}{t_{1}-t_{2}}
$$

where $X_{i}$ is the mass concentration of dry biomass in the medium at time $t_{i}$.

\section{Results and discussions}

\subsection{Effect of the aeration rate on cell growth and nitrogen consumption}

Figure 2 shows the cell growth curves in the seedbed and in the PBR at the aeration rates studied. This mode of cultivation is called two-stage cultivation, where in the first stage (the seedbed) the cells grows under nitrogen sufficiency $\left(90 \mathrm{mg} \mathrm{L}^{-1}\right)$ and in the second stage (the $\mathrm{PBR}$ ), the concentration of nitrogen is reduced considerably (to $20 \mathrm{mg} \mathrm{L}^{-1}$ ).

The idea of the two-stage cultivation mode is to stimulate the overproduction of intracellular lipids in the microalgae, at the expense of reduced cell growth [3]. 

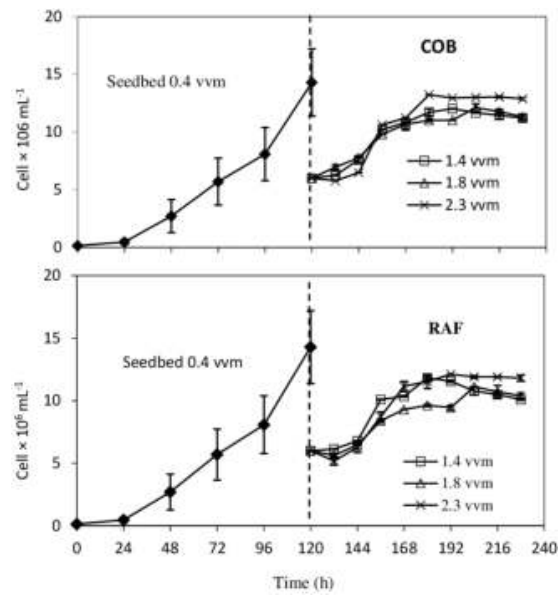

Figure 2. Cell growth curves in the seedbed and in both PBRs.

Table 1 shows the growth data (maximum value of cell density, specific growth rate $\mu$, and consumption of $\mathrm{N}-\mathrm{NH}_{4}^{+}$) for all experimental treatments.

At sufficient nitrogen conditions, the seed reactors reached high values in the cell density of $14.3 \times 10^{6}$ cells $\mathrm{mL}^{-1}$ and in the specific growth rate $\left(\mu=0.93 \mathrm{~d}^{-1}\right)$. While there is no inhibition of cell growth due to nutrient limitation, the rate of aeration is a factor that favors the contact of cells and light, reducing the effect of self-shading. This can be observed according to the results obtained (Table 1) where, with the increase of the aeration rate to values of $2.3 \mathrm{vvm}$, in both PBRs (COB and RAF) statistically significant changes were obtained in the growth parameters in comparison with the other treatments. The consumption curves of $\mathrm{N}_{-} \mathrm{NH}_{4}^{+}$ are presented in Figure 3 superimposed on the growth curves in both PBRs and at different aeration rates. Nitrogen consumption remained constant in all runs, between 30 and $38 \%$ of available nitrogen, without showing significant differences (Table 1). These nitrogen uptake values were low compared to Mata et al. [1] and Gouveia and Oliveira [13]. In Figure 3, it is observed that the consumption of nitrogen, although it occurs slowly, continues even after

\begin{tabular}{|c|c|c|c|c|c|c|}
\hline & RAF & & & СОВ & & \\
\hline & $\begin{array}{l}\text { Maximum } \\
\text { cell density } \\
\left(\text { cell } \times 10^{6} \mathrm{~mL}^{-1}\right)\end{array}$ & $\mu\left(\mathrm{d}^{-1}\right)$ & 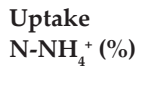 & $\begin{array}{l}\text { Maximum } \\
\text { cell density } \\
\left(\text { cell } \times 10^{6} \mathrm{~mL}^{-1}\right)\end{array}$ & $\mu\left(\mathrm{d}^{-1}\right)$ & $\begin{array}{l}\text { Uptake } \\
\mathrm{N}^{-\mathrm{NH}_{4}^{+}}(\%)\end{array}$ \\
\hline $1.4 \mathrm{vvm}$ & $11.8 \pm 0.11^{\mathrm{a}}$ & $0.31 \pm 0.002^{\mathrm{a}}$ & $32.6 \pm 1.0^{\mathrm{a}}$ & $12.0 \pm 0.03^{\mathrm{a}}$ & $0.28 \pm 0.014^{\mathrm{a}}$ & $32.2 \pm 1.0^{\mathrm{a}}$ \\
\hline $1.8 \mathrm{vvm}$ & $11.1 \pm 0.02^{\mathrm{a}}$ & $0.33 \pm 0.021^{\mathrm{a}}$ & $30.3 \pm 1.7^{\mathrm{a}}$ & $12.1 \pm 0.34^{\mathrm{a}}$ & $0.28 \pm 0.021^{\mathrm{a}}$ & $30.3 \pm 0.3^{\mathrm{a}}$ \\
\hline $2.3 \mathrm{vvm}$ & $12.1 \pm 0.00^{\mathrm{b}}$ & $0.50 \pm 0.014^{\mathrm{b}}$ & $34.2 \pm 0.4^{\mathrm{a}}$ & $13.0 \pm 0.03^{b}$ & $0.43 \pm 0.002^{\mathrm{b}}$ & $38.8 \pm 0.2^{\mathrm{a}}$ \\
\hline
\end{tabular}

Different letters in the same column indicate significant differences according to Tukey's test $(p \geq 0.05)$; ( \pm standard deviation). Data taken from doctoral thesis [34].

Table 1. Average data of maximum cell density, specific growth rates $(\mu)$, and nitrogen uptake of $C$. vulgaris in both PBRs at the proposed aeration rates. 

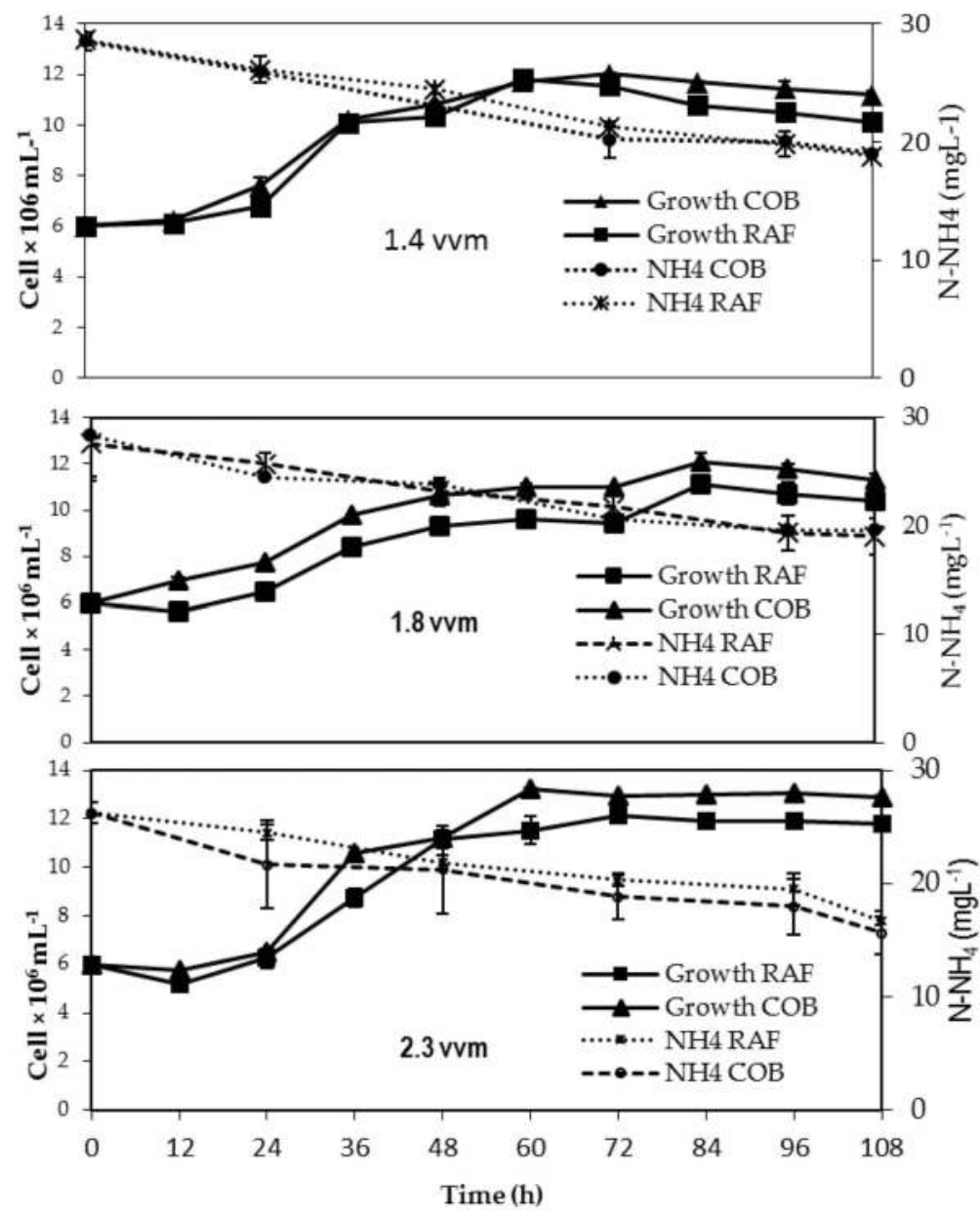

Figure 3. Growth curves and nitrogen uptake of C. vulgaris at the different aeration rates in the PBR.

the exponential phase of growth has ended. This indicates that although there was a change in the algal metabolism when going from the seed reactor to the PBR, redirecting the use of available nitrogen to storage metabolites, the limitation of growth was not exclusively due to the scarcity of nitrogen in the medium. A possible explanation for this behavior is that the cells adapted to the conditions of the culture medium to continue growing without resenting the scarcity of nitrogen. That is to say, a stress for nutrients did not occur, maintaining the metabolism acquired in the seedling stage, unlike of what is reported by [13, 15, 25-27], where nitrogen insufficiency and the phenomenon of nutrient stress were present. In addition, upon reaching the stationary phase and cell growth, microalgae would have greater difficulty in accessing light to perform the process of photosynthesis and consume nitrogen only to maintain their cellular functions and produce storage metabolites [13, 28, 29]. 
The values reached of $\mu$ in both PBRs (shown in Table 1) were statistically similar to the flows of 1.4 and $1.8 \mathrm{vvm}$; in the same way, the values of maximum average cell density in both equipments (RAF and COB) did not show significant differences between them (Table 1). From Figure 3 and Table 1, it is also possible to indicate that the specific growth rates increased in a similar way as the aeration rate in each treatment increased, showing significant differences only with respect to an aeration rate of $2.3 \mathrm{vvm}$, where a higher $\mu$ and cell density were reached for both reactors. Taking into consideration of the above and according to the increments of cell growth and specific growth rate $(\mu)$ reached at the aeration rates of 1.8 and $2.3 \mathrm{vvm}$, it can be mentioned that there were no aspects related to photoinhibition, or stress by shear or sedimentation, since there were suitable agitation and mixing conditions. Maximum cell densities between 60 and $72 \mathrm{~h}$ were reached at the aeration rate of $2.3 \mathrm{vvm}$, both in airlift and in the bubble column. The removal values of $\mathrm{N}$ were not as expected, which implies that conditions of $\mathrm{N}$ limitation were not reached, since the cells adapted to continue cell development without resenting the nitrogen shortage, maintaining the metabolism that they had in the seedling stage. It should be noted that high nitrogen consumption (85-90\%) was not obtained in the seed reactor, so that by decreasing the concentration of nitrogen at the end of the first stage (seedbed) from 60 to $20 \mathrm{mg} \mathrm{L}^{-1}$ in the PBR, the microalgae did not suffer the decrease of nitrogen in the medium. The growth parameters observed can be related to the calculated hydrodynamic data; the data of the pumping power and characteristic cutoff rate according to each of the aeration rates used are indicated in Table 2 . The biphasic flow regimes were different in each equipment, according to the gas superficial velocities applied in each PBR. To characterize the biphasic air/culture medium flow within the PBR, a classification of flow patterns is commonly used as homogeneous bubbling, slug (plug), churn (heterogeneous turbulent), and annular [30].

According to the data obtained, it was observed that the flow in the RAF reactor was maintained in the slug regime, while in the COB reactor, it presented homogeneous bubbling type. These regimes have important differences in the degree, type of agitation, and mixing. At the same pumping power, the surface velocity of the gas in the riser of the RAF is much higher than in the COB because the flow section is smaller. Consequently, the flow rate slug is considerably higher than in homogeneous bubbling, due to the greater turbulence generated between the two phases. Figure 4 compares the specific growth rate measured against the characteristic shear rate calculated for each geometry. It is observed that in spite of increasing almost twice

\begin{tabular}{lllll}
\hline PBR & Aeration rate $(\mathrm{vvm})$ & $P G / V L\left(\mathrm{Wm}^{-3}\right)$ & Ug ó $U g r\left(\mathrm{~ms}^{-1}\right)$ & $\gamma\left(\mathrm{s}^{-1}\right)$ \\
\hline COB & 1.4 & 176 & 0.018 & 134 \\
& 1.8 & 235 & 0.024 & 155 \\
& 2.3 & 294 & 0.030 & 173 \\
\multirow{2}{*}{ RAF } & 1.4 & 176 & 0.052 & 228 \\
& 1.8 & 235 & 0.070 & 264 \\
& 2.3 & 294 & 0.087 & 295 \\
\hline
\end{tabular}

Table 2. Hydrodynamic data calculated at the aeration rates studied in both PBRs. 


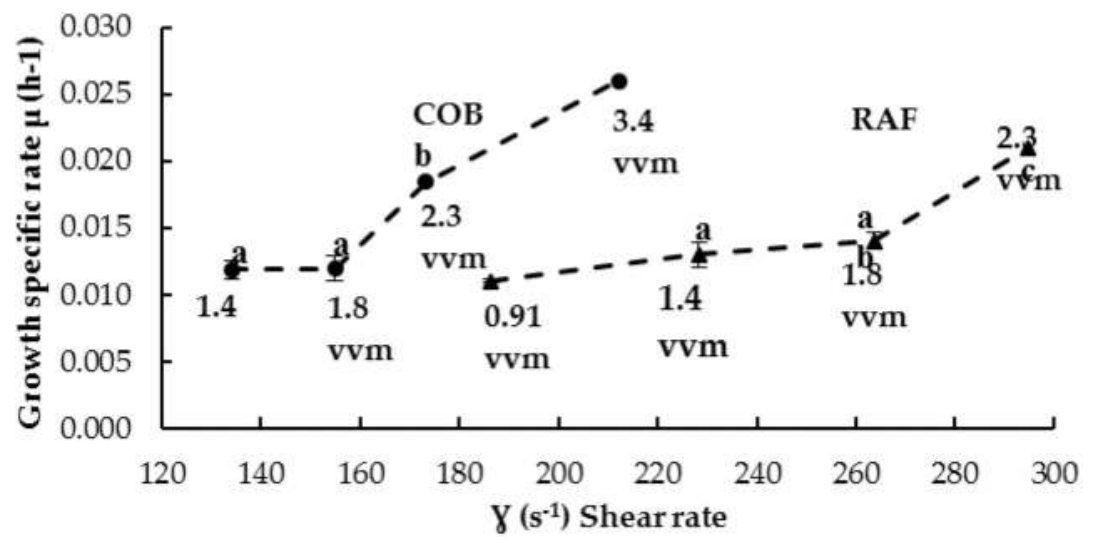

Figure 4. Maximum growth rate vs. shear rate at the airflows indicated on both equipments. Different letters indicate significant differences of shear rate at the proposed aeration rates according to Tukey's test $(\mathrm{p} \geq 0.05)$.

the shear rate in the same PBR, a negative effect was not obtained in the growth rates, as has been reported in reactors with high values of shear rate [11]. It is ruled out that in this experimental range there is a sublethal damage in the cells due to shear stress. On the contrary, at higher aeration rates, the effect of agitation and mixing dominated the shear effort, improving the gas exchange and the accessibility of light, achieving in turn specific higher growth rates.

On the other hand, Figure 5 relates the maximum cell concentration $X_{\max }$ and the calculated shear rate. An important trend of an increase of the $X_{\max }$ with the aeration rate (and the shear rate) is observed until reaching a critical value in which the increase in the shear rate does not influence $X_{\max }$ more.

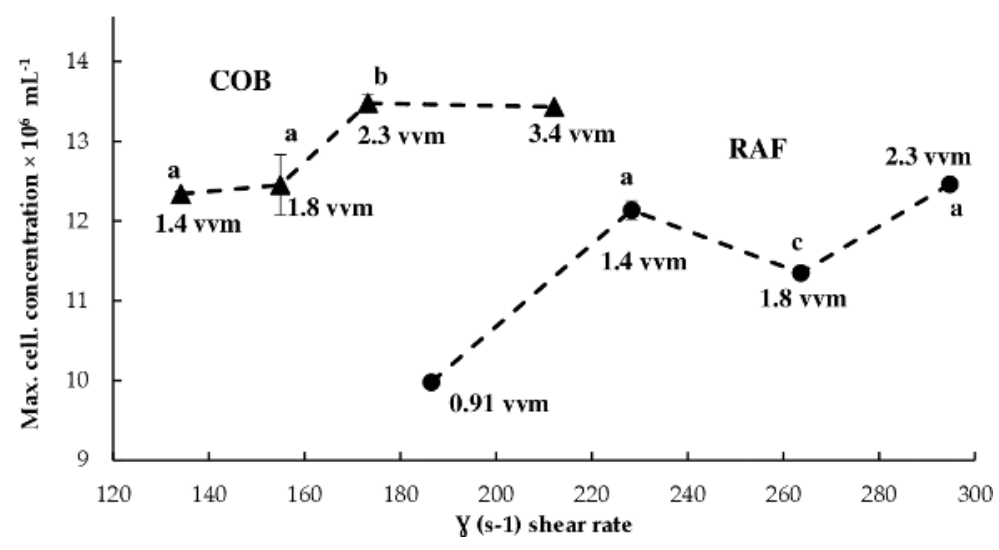

Figure 5. Maximum cell concentration vs. shear rate at the airflows indicated on both equipments. Different letters indicate significant differences of shear rate at the proposed aeration rates according to Tukey's test $(p \geq 0.05)$. 
These maximum values were found in $2.3 \mathrm{vvm}$ for COB and $1.4 \mathrm{vvm}$ for RAF. It is thus identified that the overall effect of the aeration rate on cell growth is to accelerate the growth of C. vulgaris due to better mixing, until reaching the maximum value of cell density that allows mass transfer (more likely $\mathrm{CO}_{2}$ from the gas to the cell) or the available lighting for photosynthesis. Figures 6 and 7 also include two aeration rates that were tested outside the experimental design ( $0.91 \mathrm{vvm}$ for RAF and $3.4 \mathrm{vvm}$ for $\mathrm{COB}$ ). These two values were only made to confirm the trends in the shear rates already discussed.

Due to the supplied aeration rate and configuration of both equipments, it is possible that the cells have changes in their metabolism and growth. In order to identify if there is any type of cellular damage by shear stress in both PBRs, the values of the shear rate were compared, proportional to the shear stress or also known as shear effect, calculated at the different aeration rates proposed in the experimental design $(1.4,1.8$, and $2.3 \mathrm{vvm})$. Due to the aeration rate and configuration of both equipments, it is possible that cells show changes in growth and metabolism. In order to identify if there is any type of cellular damage by shear stress
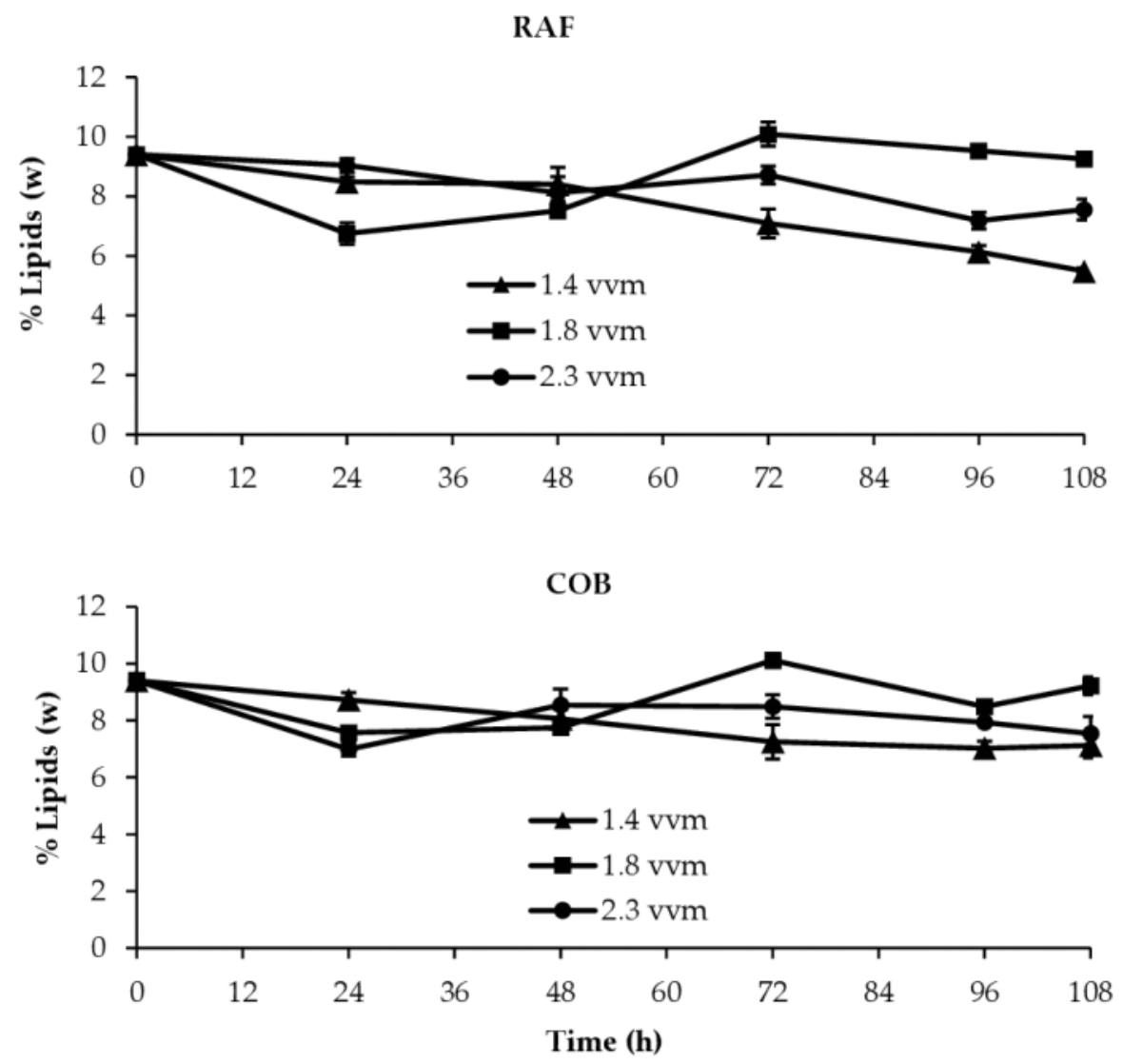

Figure 6. Kinetics of the percentage (\%) of lipids (dry basis) in both PBRs at the aeration rate studies. 

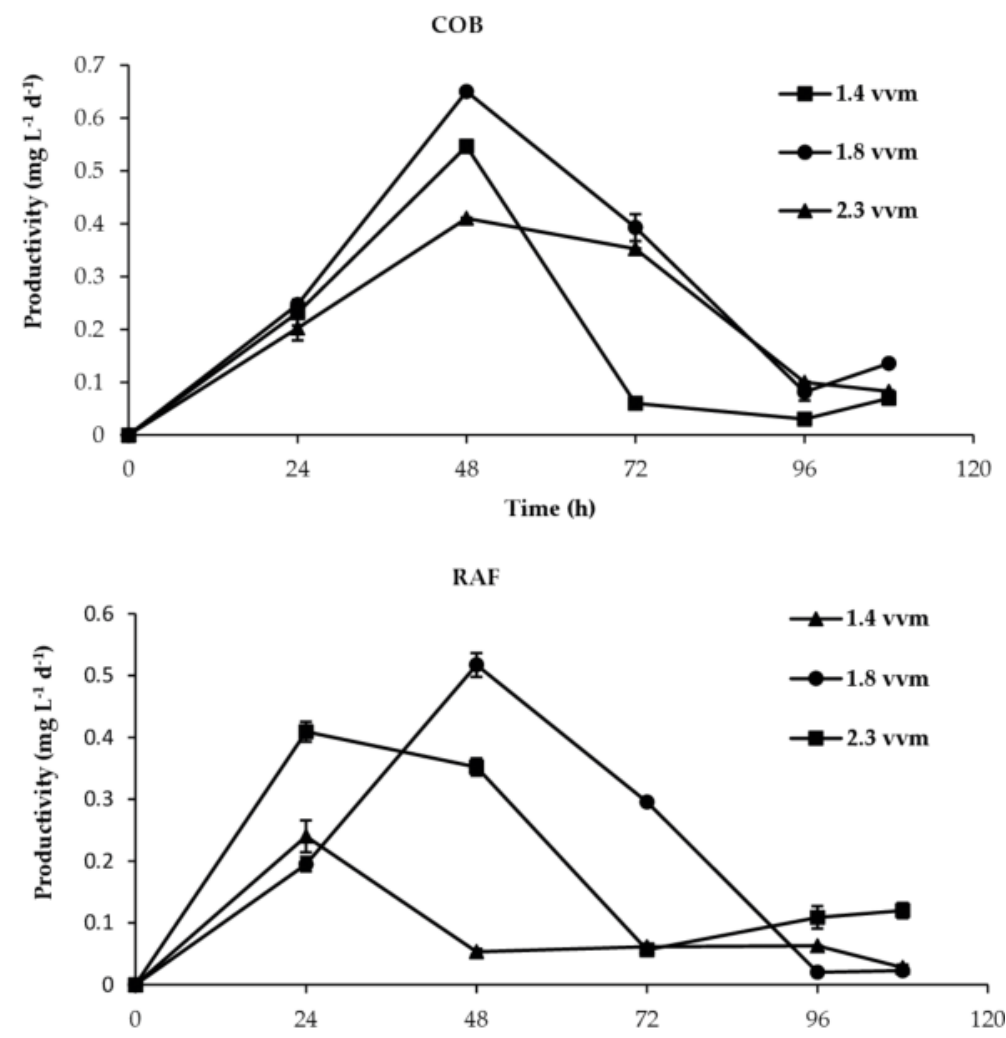

Time (h)

Figure 7. Kinetics of the lipid productivity in both PBRs at the aeration rate studies.

in both PBRs, values of the shear rate that is proportional to the shear stress or also known as shear effect were compared. These were calculated at the proposed aeration rates in the experimental design $(1.4,1.8$, and $2.3 \mathrm{vvm})$. In the RAF reactor, the flow and configuration regime caused the gas and liquid surface velocities to have higher values than in $\mathrm{COB}$, which is related to higher shear rates as aeration rates increased. These differences are related to the configuration of each reactor and in some cases can cause cell damage; however, some species can be adapted to high shear stress conditions. According to Figure 5, it can be indicated that although the RAF equipment presented values of cutoff rates about 1.5 times higher than in the COB equipment, with similar aeration flows, there was no negative effect on the specific growth rates, eliminating the possibility of sublethal damage to cells due to shear stress, in this experimental range. On the contrary, it can be pointed out that at higher aeration rates, the effect of agitation and mixing dominated the shear effort, producing higher specific rates of growth. According to the previous result, it can be demonstrated that by means of a slight modification to the geometry of the PBR it is possible to substantially change 
the characteristic agitation of the system and reduce the culture time necessary to reach the maximum cell density. However, it should be noted that the configuration of the equipment and the rate of aeration supplied could cause irregularities in the properties of microalgal cells during cultivation [31,32]. For this reason, it must be verified if this regime change does not cause effects on other important parameters of the crop, such as the lipid content and the weight of dry biomass, among others. In the same way, in Figure 4 it can be observed that the maximum aeration rate was $1.8 \mathrm{vvm}$, since by increasing the aeration flow, an increase in the specific rate of growth is manifested. This may indicate that there is a critical point around this value $(1.8 \mathrm{vvm})$ in which $C$. vulgaris adapts its metabolism and reacts to greater turbulence to increase its growth. Taking this into account, it can be assumed that at low aeration rates, the cells would have greater difficulty to access the light source and perform photosynthesis, presenting themselves with self-shading and/or less agitation, consuming the necessary nitrogen, just to maintain their functions and produce metabolites and other storage products $[13,29,30]$.

\subsection{Effect of the rate of aeration on lipid production}

The lipid content in dry base $\mathrm{w}$ and the concentration of dry biomass $\mathrm{X}$ were monitored every $24 \mathrm{~h}$ in the PBR, with the objective of performing a kinetics of the productivity of lipids $\left(\mathrm{P}_{\mathrm{L}}\right)$ for each experiment, calculated with Eq. (6). The kinetics obtained are presented in Figures 6 and 7.

In Figure 6 it can be seen that in general the lipid content was low, between 8 and 10\%, lower in a range between 22 and 30\% than in other studies [12, 13, 30, 33]. This is probably related to the fact that there was no effect of nitrogen limitation in the second stage of culture of the PBR, which caused a low lipid content. According to this condition, it can be noted that the concentration of nitrogen at the end of the first stage of the seedbed was higher than expected (45 mg L $\mathrm{m}^{-1}$. Therefore, when performing the dilution at $20 \mathrm{mg} \mathrm{L}^{-1}$ in the PBRs, the volume of inoculum in relation to the number of cells did not show the effect of nitrogen limitation from the beginning, despite the fact that cell growth during the culture process in the equipment doubled. This situation suggests that the microalgae adapted to continue with their growth metabolism and by not resenting the change due to the reduction or limitation of nutrients in the culture medium in the PBR; the cells grew in number, without achieving a greater amount of lipids for storage. This situation of low lipid performance was related to the results of low nitrogen consumption in all treatments. In the RAF experiments, the lipid content decreased throughout the crop, with the exception of the culture at $1.8 \mathrm{vvm}$, where it decreased during the first $48 \mathrm{~h}$, but a maximum peak was observed at $72 \mathrm{~h}$. This value $(10.3 \%)$ was also the maximum observed in all the curves. The same behavior is observed for the COB. The maximum lipid productivity values occur after $48 \mathrm{~h}$ of culture in RAF and $24 \mathrm{~h}$ in COB (see Figure 7), with the notable exception in the latter of the experiment at $1.8 \mathrm{vvm}$ that occurred after $48 \mathrm{~h}$. The behavior of productivity kinetics is due to the fact that cell density reaches a maximum of around $48 \mathrm{~h}$ and the lipid content remains relatively constant, so as time goes on increasing, productivity decreases, according to Eq. (6).

Table 3 shows the results related to the production of lipids in both PBRs at the different rates of aeration. It is observed that the variations in lipid content are only significantly different 


\begin{tabular}{llllll}
\hline PBR & Aeration rate $(\mathrm{vvm})$ & $X\left(g L^{-1}\right)$ & $w_{\max }\left(\% w w^{-1}\right)$ & Maximum $P_{L}\left(m g L^{-1} d^{-1}\right)$ & Increase in $P_{L}^{+}(\%)$ \\
\hline RAF & 1.4 & $0.13 \pm 0.042^{\mathrm{a}}$ & $8.36 \pm 0.01^{\mathrm{a}}$ & $0.240 \pm 0.012^{\mathrm{a}}$ & 120 \\
& 1.8 & $0.27 \pm 0.042^{\mathrm{b}}$ & $10.37 \pm 0.00^{\mathrm{b}}$ & $0.528 \pm 0.002^{\mathrm{b}}$ & 70 \\
& 2.3 & $0.16 \pm 0.021^{\mathrm{a}}$ & $9.12 \pm 0.01^{\mathrm{a}}$ & $0.408 \pm 0.025^{\mathrm{c}}$ & 17 \\
CBA & 1.4 & $0.22 \pm 0.056^{\mathrm{a}}$ & $8.54 \pm 0.00^{\mathrm{a}}$ & $0.552 \pm 0.026^{\mathrm{b}}$ & -26 \\
& 1.8 & $0.30 \pm 0.010^{\mathrm{b}}$ & $10.28 \pm 0.00^{\mathrm{b}}$ & $0.650 \pm 0.019^{\mathrm{d}}$ & $0.410 \pm 0.016^{\mathrm{c}}$ \\
\hline
\end{tabular}

"Different letters in the same column indicate significant differences according to Tukey's test $(p \geq 0.05)$; ( \pm standard deviation). Data taken from doctoral thesis [34].

${ }^{\dagger}$ Increase in lipid productivity with respect to $1.4 \mathrm{vvm}$

Table 3. Dry biomass $\mathrm{X}$, lipid content $\mathrm{w}$, and maximum $\mathrm{P}_{\mathrm{L}}$ lipid productivity in both PBRs at the proposed aeration rates.

from the $1.8 \mathrm{vvm}$ aeration rate for both PBRs. The observed changes in lipid productivity are mainly affected by the lipid content $\mathrm{w}$, not so much for the concentration of dry biomass $\mathrm{X}$, since statistically no significant differences are observed in the data obtained from the biomass in both PBRs at the rate of aeration (see Table 3).

Although the highest percentage of the increase in productivities occurred in the RAF $(120 \%)$, in COB the highest lipid productivity observed was $0.65 \mathrm{mg} \mathrm{L}^{-1} \mathrm{~d}^{-1}$. Since the values of lipid content were not very different between geometries, the difference in productivity can be attributed to the fact that in $\mathrm{COB}$ higher cell growths were achieved. According to the values reached in Figure 7 and Table 3, it is observed that in COB the highest value of lipid productivity was obtained at $48 \mathrm{~h}$ with respect to all aeration rates with $0.65 \mathrm{mg} \mathrm{L}^{-1} \mathrm{~d}^{-1}$; in addition, as already mentioned, cell growth has a greater impact in relation to the reached value of lipid productivities. In relation to the RAF reactor, the highest productivity $\left(0.528 \mathrm{mg} \mathrm{L}^{-1} \mathrm{~d}^{-1}\right)$ was obtained at $48 \mathrm{~h}$ at the $1.8 \mathrm{vvm}$ aeration rate; later, a decay was observed until the end of the experiment, and this was due to a reactivation by agitation, affecting cell growth, generating a cellular increase. The results of lipid productivities were not the expected ones, since they were in the range of $0.2-0.650 \mathrm{mg} \mathrm{L}^{-1} \mathrm{~d}^{-1}$, that is, $40 \%$ lower, compared with other studies that used similar conditions in the cultivation process with microalgae, $[5,13,26]$. This situation would confirm in a certain way what had been supposed previously.

\section{Conclusions}

The interest of this work was to evaluate the effect of hydrodynamic conditions at different aeration rates, on lipid productivity and other parameters such as cell growth, specific growth rate, nitrogen removal, and lipid accumulation of Chlorella vulgaris in cultures with nitrogen limitation using two geometries of PBRs (bubble column and airlift). In relation to cell growth, the values of $\mu$ in both PBRs were statistically similar with $0.312 \mathrm{~d}^{-1}$ at an aeration flow of $1.4 \mathrm{vvm}$. While at the aeration rate of $1.8 \mathrm{vvm}, \mu$ was $0.336 \mathrm{~d}^{-1}$ for the reactor RAF, while in COB the 
value of $\mu$ was $0.288 \mathrm{~d}^{-1}$ for the same aeration rates (1.4 and $\left.1.8 \mathrm{vvm}\right)$. Similarly, the values of maximum average cell density in both equipments did not show significant differences between them $(11.82$ and 11.11$) \times 10^{6}$ cells $\mathrm{mL}^{-1}$ to $(1.4$ and $1.8 \mathrm{vvm})$ for the reactor RAF; while in reactor COB the average cell density was (12.00 and 12.11$) \times 10^{6}$ cells $\mathrm{mL}^{-1}$ to $(1.4$ and $1.8 \mathrm{vvm})$. However, specific growth rates increased $\left(0.504\right.$ and $\left.0.432 \mathrm{~d}^{-1}\right)$ in RAF and COB, respectively, as long as it increases the aeration rate in each treatment, showing significant differences only with respect to an aeration rate of $2.3 \mathrm{vvm}$ for both PBRs. According to the increments reached of cell growth and specific growth rate $(\mu)$ at the aeration rates of 1.8 and $2.3 \mathrm{vvm}$, it can be mentioned that there were no related to photoinhibition nor stress by shear or sedimentation, since the conditions of agitation mixing were sufficient. Both equipments presented different agitation flows according to the proposed aeration rates. It can be mentioned that the biphasic flow regimes were different in each equipment, due to the differences in the values of the superficial gas velocities calculated at the proposed aeration rates. According to the values obtained from the gas velocity, it is observed that in the airlift the working regime was in the Slug type flow range, while in the bubbling column it was developed as a homogeneous bubbling type. This speaks to the degree of agitation and mixing that existed in each team. $\mathrm{N}$ limiting conditions were not reached; this is probably because the cells achieved an early adaptation to low concentrations of nitrogen, supporting their metabolism and growth from the seed reactor stage, where high nitrogen consumption was not obtained (85-90\%). So that by decreasing the concentration of nitrogen (45 mg $\mathrm{L}^{-1}$ ) at the end of the first stage (seedbed) to $20 \mathrm{mg} \mathrm{L}^{-1}$ in the PBR, the microalgae did not suffer the decrease of nitrogen in the medium. Although it was observed that increasing the aeration rate also increased cell growth, the highest possible lipid production was not reached in these bioreactor geometries. In general, the lipid content was low, between 8 and 10\%, lower in a range between 22 and 30\% than in other studies. In the COB reactor, the highest lipid productivity value $\left(0.650 \mathrm{mg} \mathrm{L}^{-1} \mathrm{~d}^{-1}\right)$ was obtained at $48 \mathrm{~h}$ with respect to all aeration rates. In relation to the RAF reactor, the highest productivity $\left(0.528 \mathrm{mg} \mathrm{L}^{-1} \mathrm{~d}^{-1}\right)$ was obtained at $48 \mathrm{~h}$ at the $1.8 \mathrm{vvm}$ aeration rate; later, a decay was observed until the end of the experiment, and this was due to a reactivation by agitation, affecting cell growth. The achieved results of lipid productivities were not as expected since they were in the range of $0.2-0.650 \mathrm{mg} \mathrm{L}^{-1} \mathrm{~d}^{-1}$, that is, $40 \%$ lower, compared with other studies that used similar conditions. Although the highest percentage of the increase in productivities occurred in the RAF reactor $(120 \%)$, in the COB reactor, the highest lipid productivity $\left(0.65 \mathrm{mg} \mathrm{L}^{-1} \mathrm{~d}^{-1}\right)$ was observed. Since the values of lipid content were not very different between both geometries, mainly at the aeration rate of $1.8 \mathrm{vvm}(10.28$ and 10.37$) \% w w^{-1}$, the difference in productivity can be attributed to the fact that the $\mathrm{COB}$ reached higher values of cell growths. The results obtained are probably related to the fact that there was no effect of limiting nitrogen in the second stage of cultivation of the PBR, which caused a low lipid content, as already mentioned.

\section{Acknowledgements}

The National Council of Science and Technology (CONACyT) funded this research through projects 145521 and Basic Science 179857. 


\section{Conflict of interest}

The authors indicate that there is no conflict of interest for the publication of this manuscript.

\section{Nomenclature}

A

RAF

$\mathrm{Ab}$

COB

cells $\mathrm{mL}^{-1}$

$\mathrm{d}_{\mathrm{bi}}$

$\mathrm{d}_{\mathrm{bo}}$

$\mathrm{d}_{\mathrm{h}}$

$\mathrm{d}_{\mathrm{i}}$

d.i.

$\mathrm{d}_{\mathrm{o}}$

PBR

$\mathrm{Fg}$

g

$\mathrm{h}_{\mathrm{B}}$

$\mathrm{h}_{\mathrm{G}}$

$\mathrm{h}_{\mathrm{L}}$

kB

$m g L^{-1} d^{-1}$

n.d.

$\mathrm{P}_{\mathrm{L}}$

rpm

Ton

$\mathrm{U}_{\mathrm{g}}$
Absorbance

Airlift reactor

Free area between the riser and the downcomer in $\mathrm{m}^{2}$

Bubble column

Cells per milliliter

Internal diameter of the deflector $(\mathrm{m})$

External diameter of the deflector $(\mathrm{m})$

Hydraulic diameter

Diameter of the inner tube where the lighting is performed (m)

Internal diameter

External diameter of the external tube (m)

Photobioreactor

Air intake flow in $\mathrm{m}^{-3} \mathrm{~s}^{-1}$

Acceleration of gravity in $\mathrm{m} \mathrm{s}^{-2}$

Distance between base and deflector $(\mathrm{m})$

Height of the column including gas retention (m)

Height of liquid at rest without gas inlet (m)

Coefficient of friction loss

Milligrams per liter per day

Not detectable

Lipid productivity

Revolutions per minute

Ton

Superficial gas velocity in $\mathrm{ms}^{-1}$ 
$\mathrm{U}_{\mathrm{L}} \quad$ Liquid superficial velocity in $\mathrm{ms}^{-1}$

vvm Volumetric airflow (per minute) per unit volume of medium in $\mathrm{min}^{-1}$

$\mu \mathrm{E} \mathrm{m} \mathrm{m}^{-2} \mathrm{~s}^{-1} \quad$ Microeinstein per square meter per second

\section{Author details}

Juan Carlos Robles Heredia ${ }^{1 *}$, Asteria Narváez García ${ }^{1}$, Alejandro Ruiz Marin ${ }^{1}$, Yunuen Canedo Lopez ${ }^{1}$, Jose del Carmen Zavala Loria ${ }^{2}$ and Julio Cesar Sacramento Rivero ${ }^{3}$

*Address all correspondence to: jrobles@pampano.unacar.mx

1 Autonomus University of Carmen, Carmen City, Campeche, México

2 International University Iberoamerican, Campeche, México

3 Autonomus University of Yucatán, Mérida, Yucatán, México

\section{References}

[1] Mata TM, Martins AA, Caetano NS. Microalgae for biodiesel production and other applications: A review. Renewable and Sustainable Energy Reviews. 2010;14:217-232. DOI: 10.1016/j.rser.2009.07.020

[2] Xin L, Hong-Ying H, Ke G, Ying-Xue S. Effects of different nitrogen and phosphorus concentrations on the growth, nutrient uptake, and lipid accumulation of a freshwater microalga Scenedesmus sp. Bioresource Technology. 2010;101:5494-5500. DOI: 10.1016/j. biortech.2010.02.016

[3] Robles-Heredia JC, Sacramento-Rivero JC, Canedo-López Y, Ruiz-Marín A, VilchizBravo LE. A multistage gradual nitrogen-reduction strategy for increased lipid productivity and nitrogen removal in wastewater using Chlorella vulgaris and Scenedesmus obliquus. Brazilian Journal of Chemical Engineering. 2015;32:335-345. DOI: 10.1590/ 0104-6632.20150322s00003304

[4] Fernández LLC, Montiel MJ, Millán OP. Production of biofuels from microalgae. Ra Ximhai. 2012;8(3b):101-115. ISSN: 1665-0441

[5] Mujtaba G, Choi W, Lee C, Lee K. Lipid production by Chlorella vulgaris after a shift from nutrient-rich to nitrogen starvation conditions. Bioresource Technology. 2012;123:279-283. DOI: 10.1016/j.biortech.2012.07.057

[6] Griffiths MJ, Hille RP, Harrison STL. Lipid productivity, settling potential and fatty acid profile of 11 microalgal species grown under nitrogen replete and limited conditions. Journal of Applied Phycology. 2012;24:998-1001. DOI: 10.1007/s10811-011-9723-y 
[7] Grobbelaar JU. Microalgal biomass production: Challenges and realities. Photosynthesis Research. 2010;106:135-134. DOI: 10.1007/s11120-010-9573-5

[8] Monkonsit S, Powtongsook S, Pavasant P. Comparison between airlift photobioreactor and bubble column for Skeletonema costatum cultivation. Engineering Journal. 2011;15(4): 53-64. ISSN: 0125-8281

[9] Natsume T, Yoshimoto M. A method to estimate the average shear rate in a bubble column using liposomes. Industrial and Engineering Chemistry Research. 2013;52(51):18498-18502. DOI: $10.1021 / \mathrm{ie} 402874 \mathrm{q}$

[10] Martínez GL. $\mathrm{CO}_{2}$ removal with autochthonous microalgae [Thesis]. Spain: University of León; 2011

[11] Hincapie E. Design, construction and validation of an internally-lift airlift FBR [Thesis]. Faculty of the Russ College of Engineering and Technology of Ohio University; 2010

[12] Widjaja A, Chien C, Ju Y. Study of increasing lipid production from fresh water microalgae Chlorella vulgaris. Journal of the Taiwan Institute of Chemical Engineers. 2009;40:13-20. DOI: 10.1016/j.jtice.2008.07.007

[13] Gouveia L, Oliveira AC. Microalgae as a raw material for biofuels production. Journal of Industrial Microbiology and Biotechnology. 2009;36:269-274. DOI: 10.1007/s10295-0080495-6

[14] Chiu S, Kao C, Chen C, Kuan T, Ong S, Lin C. Reduction of $\mathrm{CO}_{2}$ by a high density culture of Chlorella sp. in a semicontinuous photobioreactor. Bioresource Technology. 2008;99:3389-3396. DOI: 10.1016/j.biortech.2007.08.013

[15] Solovchenco AE, Khozin-Goldberg I, Didi-Cohen S, Cohen Z, Merzlyak MN. Effects of light intensity and nitrogen starvation on growth, total fatty acids and arachidonic acid in the green microalga Parietochloris incise. Journal of Applied Phycology. 2008;20:245-251. DOI: $10.1007 / \mathrm{s} 10811-007-9233-0$

[16] Ruiz-Marin A, Mendoza-Espinosa LG, Stephenson T. Growth and nutrient removal in free and immobilized green algae in batch and semicontinuous cultures treating real wastewater. Bioresource Technology. 2010;101:58-64. DOI: 10.1016/j.biortech.2009.02.076

[17] Guillard RLL, Ryther JH. Studies on marine planktonic diatoms I. Cyclotella nana Hustedt, and Detonula confervacea (Cleve). Gran. Canadian Journal of Microbiology. 1962;8:229-239. DOI: 10.1139/m62-029

[18] STATISTICA V7 (Data Analysis Software System), Version 7. StatSoft, Inc.; 2004

[19] Cerri MO, Futiwaki L, Jesus CDF, Cruz AJG, Badino AC. Average shear rate for nonNewtonian fluids in a concentric-tube airlift bioreactor. Biochemical Engineering Journal. 2008;39:51-57. DOI: 10.1016/j.bej.2007.08.009

[20] Doran PM. Bioprocess Engineering Principles. London: Academic Press Limited; 1995

[21] Chisti Y. Air Lift Bioreactors. New York: Elsevier Applied Science; 1989 
[22] Romero LT, Ferrán C. Flocculation of Chlorella sp. with the use of chitosan. Revista de Investigaciones Marinas. 2001;22(1):57-62

[23] Salazar-Leyva JA, Lizardi-Mendoza J, Ramírez-Suarez JC, García-Sánchez G, EzquerraBrauer JM, Valenzuela-Soto EM, Carvallo-Ruiz MG, Lugo-Sánchez ME, Pacheco-Aguilar R. Utilización de materiales a base de quitina y quitosano en la inmovilización de proteasas: efectos en su estabilización y aplicaciones. Revista Mexicana de Ingeniería Química. 2014;13(1):129-150. ISSN: 1665-2738

[24] Bligh EG, Dyer WJ. A rapid method of total lipid extraction and purification. Canadian Journal of Biochemistry and Physiology. 1959;(8):911-917. DOI: 10.1139/059-099

[25] Takagi M, Watanabe K, Yamaberi K, Yoshida T. Limited feeding of potassium nitrate for intracellular lipid and triglyceride accumulation of Nannochloris sp. UTEX LB1999. Applied Microbiology and Biotechnology. 2000;54(1):112-117. DOI: 10.1007/s002530000333

[26] Mazzuca-Sobczuka T, Chisti Y. Potential fuel oils from the microalga Choricystis minor. Journal of Chemical Technology and Biotechnology. 2010;85:100-108. DOI: 10.1002/ jctb.2272

[27] Li Q, Du W, Liu D. Perspectives of microbial oils for biodiesel production. Applied Microbiology Biotechnology. 2008;80:749-756. DOI: 10.1007/s00253-008-1625-9

[28] Scragg AH, Illman AM, Carden A, Shales SW. Growth of microalgae with increased calorific values in a tubular bioreactor. Biomass and Bioenergy. 2002;29:67-73. DOI: 10.1016/ S0961-9534(02)00028-4

[29] Sheehan J, Dunahay T, Benemann J, Roessler P. A Look Back at the U.S. Department of Energy's Aquatic Species Program-Biodiesel from Algae. 1998; NREL/TP-580-24190

[30] Brill JP, Mukherjee H. Multiphase Flow in Wells. Society of Petroleum Engineers. No. $17 ; 1999$

[31] Rodolfi L, Chini Zittelli G, Bassi N, Padovani G, Biondi N, Bonini G, Tredici MR. Microalgae for oil: Strain selection, induction of lipid synthesis and outdoor mass cultivation in a low-cost photobioreactor. Biotechnology and Bioengineering. 2009;102:100-112. DOI: 10.1002/bit.22033

[32] Xu H, Miao X, Wu Q. High quality biodiesel production from a microalga Chlorella protothecoides by heterotrophic growth in fermenters. Journal of Biotechnology. 2006; 126:499-507. DOI: 10.1016/j.jbiotec.2006.05.002

[33] Soto-León S, Zazueta-Patrón IE, Piña-Valdez P, Nieves-Soto M, Reyes-Moreno C, Contreras-Andrade I. Extracción de lípidos de Tetraselmis suecica: Proceso asistido por ultrasonido y solventes. Revista Mexicana de Ingeniería Química. 2014;13(3):723-737. ISSN 1665-2738

[34] Robles-Heredia JC. Evaluación de la productividad de lípidos en Chlorella vulgaris y Scenedesmus obliquus bajo dos modos de limitación de nitrógeno en fotobiorreactores tipo airlift y columna de burbujeo [thesis]. Mérida, México: Autonomus University of Yucatán; 2014 
